\title{
THE SOCIAL NETWORK FOR CONFRONTING CONJUGAL VIOLENCE: REPRESENTATIONS OF WOMEN WHO EXPERIENCE THIS HEALTH ISSUE $^{1}$
}

\author{
Nadirlene Pereira Gomes², Normélia Maria Freire Diniz³, Luana Araújo dos Reis, Alacoque Lorenzini \\ Erdmann ${ }^{5}$
}

\footnotetext{
${ }^{1}$ Work extracted from the thesis - Forging paths for confronting conjugal violence, presented to the Postgraduate Program of the School of Nursing of the Universidade Federal da Bahia (EE/UFBA), in 2009.

${ }^{2}$ Ph.D. in Nursing. Adjunct Professor of the EE/UFBA. Salvador, Bahia, Brazil. E-mail: nadirlenegomes@hotmail.com

${ }^{3}$ Ph.D. in Nursing. Adjunct Professor of the EE/UFBA. Salvador, Bahia, Brazil. E-mail: normeliadiniz@gmail.com

${ }^{4}$ Master's degree student, Postgraduate Program in Nursing, EE/UFBA. Salvador, Bahia, Brazil. E-mail: luareis1@hotmail.com

${ }^{5}$ Ph.D. in Philosophy of Nursing. Full Professor of the Department of Nursing of the Universidade Federal de Santa Catarina. Florianópolis, Santa Catarina, Brazil. E-mail: alacoque@newsite.com.br
}

\begin{abstract}
This qualitative research, grounded in Social Representations Theory, aimed to describe, based on the representations of women with a history of undergoing conjugal violence, the elements which constitute the social support network for confronting this health problem. Interviews were held with 11 women with a history of experiencing conjugal violence. The data were categorized using thematic analysis. The study shows that support from religion, family members, friends and NGO, such as the Calafate Women's Collective allows the women to feel supported, favoring the search for a life without violence. Knowledge regarding the social support network available in the community is essential for the professionals who work in the spaces of health, especially when the elements which it is composed of reflect the representations of a specific group, therefore configuring a common knowledge which is shared by the community. DESCRIPTORS: Violence against women. Family. Social help. Networks. Nursing.
\end{abstract}

\section{REDE SOCIAL PARA O ENFRENTAMENTO DA VIOLÊNCIA CONJUGAL: REPRESENTAÇÕES DE MULHERES QUE VIVENCIAM O AGRAVO}

RESUMO: Pesquisa qualitativa, fundamentada na Teoria das Representações Sociais, que teve como objetivo descrever, a partir das representações de mulheres com história de violência conjugal, os elementos que constituem a rede de apoio social para o enfrentamento do agravo. Foram entrevistadas 11 mulheres com história de violência conjugal. Os dados foram categorizados mediante a análise temática. O estudo mostra que o apoio religioso, de familiares, de amigos e de ONGs, como o Coletivo de Mulheres do Calafate, permitem às mulheres se sentirem amparadas, o que favorece a busca por uma vida sem violência. É fundamental o conhecimento acerca da rede de apoio social disponível na comunidade pelos profissionais que atuam nos espaços da saúde, especialmente quando os elementos que a integram refletem as representações de determinado grupo, configurando, portanto, um saber comum e compartilhado da comunidade. DESCRITORES: Violência contra a mulher. Família. Apoio social. Redes de apoio social. Enfermagem.

\section{RED SOCIAL PARA EL ENFRENTAMIENTO DE LA VIOLENCIA CONYUGAL: REPRESENTACIONES DE MUJERES QUE VIVEM ESTA SITUACIÓN}

RESUMEN: Esto es un estudio cualitativo, basado en la Teoria de las Representaciones Sociales, cuyo objetivo es de describir, a traves las representaciones de mujeres que tuvieran historia de violencia conyugal, los elementos que constituyen la rede social de enfrentamiento del problema. 11 mujeres que tuvieran historia de violencia conyugal fueran entrevistadas. Los dados fueran categorizados por medio de la analise tematica. Lo estudio muestra que la ayuda de la religion, de la familia, de los amigos y de ONGs como el colectivo de mujeres calafate ayuda las mujeres a se sentiren amparadas, y eso ayuda en su busca por una vida sin violencia. El conocimiento acerca de la rede de apoyo disponivel en la comunidad por profisionales que atuan en espacios de salud es fondamental, sobretodo cuando los elementos que lo integran refleten las representaciones de certo grupo, configurando, portanto, un conocimiento comun compartido por la comunidad.

DESCRIPTORES: Violencia contra la mujer. Familia. Apoyo social. Redes sociales. Enfermería. 


\section{INTRODUCTION}

Violence is understood as the use of power or physical strength against another person, group or community, leading to privation, lack of development, psychological suffering, injury or death. ${ }^{1}$ The profile of morbidity and mortality resulting from this justifies the need for actions for confronting it.

Considering violence which does not result in deaths or serious injuries - but which oppresses and causes harm to the individuals who are chronically abused - to be "invisible", the World Health Organization (WHO) proposes, in the World Report on Violence and Health, the recognition of domestic and intrafamily violence, calling attention to cases of violence which are sexual, psychological or physical, or which involve privation, coercion or neglect, and which mainly affect women, children, and the elderly. ${ }^{2}$

The Convention of Belém do Pará, adopted in 1994 in the ambit of the Organization of American States, considers the elimination of violence against women to be an indispensable condition for their individual and social development in all spheres of life. ${ }^{3}$ However, we continue to face a high rate of this issue. Violence is responsible for approximately $7 \%$ of all deaths of women aged between 15 and 44 years old worldwide. In Brazil, in particular, approximately 20,000 women died between 2003 and 2007 as a result of the violence which they suffered. ${ }^{4}$ The mortality statistics suggest that a woman is killed once every two hours, placing Brazil in $12^{\text {th }}$ position in the world classification for homicide of women. ${ }^{5}$

The majority of these violent acts occur in the domestic environment, and the woman generally knows the aggressor. These are acts of physical, psychological, sexual and patrimonial aggression which can even culminate in the woman's death through suicide or homicide. ${ }^{4}$ Regarding morbidity, studies show that in addition to resorting to specialized services, women seek help in the health services. $^{6-9}$

According to data from the Bureau for Women's Policies, 38,020 women are physically assaulted each day in Brazil. In $68.8 \%$ of cases, the aggressors are the spouse, partner or ex-husband. ${ }^{10}$ That is to say, the most frequent type of interpersonal violence worldwide is conjugal violence, and involves any type of violent act existing in romantic relationships, whether these are legalized or not. ${ }^{11}$
The first federal Brazilian law made with a view to creating mechanisms for curbing and preventing domestic and family violence against women was Law n. 11340, the Maria da Penha Law, implanted on August $7^{\text {th }}$ 2006. In Article 8, it called for an articulated set of actions from the Union, the States, the Federal District and from the Municipalities, and for non-governmental actions.

This network can be made up of police, judicial, psycho-social and medical assistance services. Other local non-institutional resources can also be actioned, such as Non-Governmental Organizations (NGO), religious, cultural or educational groups, or community or neighborhood support groups. ${ }^{13}$ This web of relationships, considered significant by the individual, and which promote social links, is referred to as the social network.

The links established in this process occur interpersonally, with friends, relatives, work or school colleagues and health professionals, who are referred to as forms of social support. In other words, social support is linked to help, to support in critical moments of life, and/or to offering information which promotes the increasing of self-esteem and allows conditions for confronting adversity. ${ }^{14}$ In the light of the above, we ask ourselves: which elements make up the social support network for women experiencing situations of conjugal violence?

One study undertaken in Rio de Janeiro and São Paulo showed that the health support network is not always present for the individuals, ${ }^{15}$ which indicates the need to consider other support resources for the person in a situation of vulnerability. The social network is a political strategy in situations of social vulnerability, being an important element for confronting crisis situations, ${ }^{16}$ such as, for example, the experience of conjugal violence.

Considering the repercussions of the experience of violence for women's health, and taking into account that social support influences decisions and actions adopted for confronting the situation, this study aims to describe, based on the representations of women with a history of experiencing conjugal violence, the elements which make up the social support network for confronting this health problem.

\section{METHODOLOGY}

This is an exploratory study with a qualitative approach, grounded in Social Representa- 
tions Theory (SRT). The qualitative approach is considered appropriate to this study's object, as it constitutes a method which is concerned with observing deeper aspects of human complexity, allowing a more detailed interface regarding attitudes and behavioral tendencies. ${ }^{17}$ This approach is relevant for understanding the subjectivities which permeate the conjugal relationship, in particular, that which relates to the seeking of social support on the part of the woman for confronting conjugal violence.

Studies point to the fact that social support has to do with information, beliefs, and, above all, the relationship between individuals inserted in a social context and their social environment. The interpretation of such relationships makes it possible to investigate the worldview of the subjects in relation to the context or object. ${ }^{18-20}$ This shared form of knowing and communicating in routine life guides the actions in social relationships, determining the behaviors and practices of a specified group. Social Representations Theory is based on this assumption.

Based in SRT, the social representations constitute an organized set of information, attitudes, values, beliefs and opinions which an individual or group elaborates regarding an object or situation, presenting, therefore, a subjective and social vision of the context. It is this world view which guides how the individuals of a group act and take decisions. ${ }^{21}$ From this perspective, it is believed that this framework makes it possible to know how the women act in relation to looking for resources to strengthen themselves and help them to confront the issue of conjugal violence.

The study setting was the community of Calafate, located in the neighborhood of San Martin in Salvador, in the state of Bahia (BA), Brazil. The approach to the community was made with the help of an NGO: the Calafate Women's Collective (CMC). Set up in 1992, due to the high rate of domestic violence in the community, the CMC promotes lectures, workshops, and conversation circles with the objective of providing information referent to ensuring human rights. These activities are linked to partnerships, such as with the Network for Attention to Women in Situations of Violence, the AIDS Prevention Support Group (GAPA), Universidade do Estado da Bahia (UNEB) and the Universidade Federal da Bahia (UFBA).

The partnership with the UFBA occurs through research and extension projects linked to research groups (the Women's Health Studies
Group and the Research on Violence, Health and Quality of Life Group) of the School of Nursing of the Federal University of Bahia. Since 1997, the Calafate Women's Collective has undertaken workshops on health and violence for women resident in this community.

The participants in the study were women living in this community, aged at least 18 years old, and with a history of experiencing conjugal violence. As it works with social thinking, which is anchored in the diversity of the knowledge learned in the routine life of the social relationships, SRT allows a specific interpretation of one group regarding a specific object. ${ }^{21}$ In this study, we sought, based on the social representations of women in situations of conjugal violence, to grasp the elements which make up the social support network for confronting this health issue.

As the community which is the locus of the study has been the setting of activities linked to UFBA for 15 years, the interviews revealed that all the women interviewed have participated, at some point, in the above-mentioned workshops. It is worth emphasizing, however, that the sample was not intentional, as the educational activities are a peculiarity of this community, as they are ongoing actions of the CMC.

The contact with the women was made with the support of members of the CMC, who accompanied the researchers in the women's houses. At these times, the study's objectives and relevancy were explained to them and they were invited to be collaborators in the same. We also said to them that they had the right to choose to participate or not in the study and/or to withdraw from the study at any time, that there would be no material or financial compensation for participating, and that we would guarantee the confidentiality of the information and their anonymity, through the use of fictitious names (Greek goddesses), among other ethical aspects, in accordance with Resolution 196/96. Having accepted to participate in the study, the collaborators signed the terms of consent. Data collection was begun following the approval of the project by the Research Ethics Committee of the Santo Antônio Hospital, under n. 31/07.

The interviews were held in March - October 2008 , in the physical space of the CMC, at times when no activities were being undertaken, so as to ensure the women's privacy. As the data collection technique, we opted for in-depth interviews, held based on a questionnaire with the following guiding question: which social support resources 
do/did you seek for confronting the conjugal violence? The technique of in-depth interview, frequently used in exploratory studies, allows the interviewee to speak freely, and the interviewer to discover the spontaneous tendencies instead of directing them, which enriches the investigation. ${ }^{22}$ The analysis of the data occurred at the same time as the collection, indicating saturation in the $11^{\text {th }}$ interview. Theoretical saturation is considered to be the point at which the narratives no longer add information to the thematic categories. ${ }^{23}$

The data obtained were organized based on the content analysis, thematic analysis being selected, which can be applied to direct discourses (manifested meanings) and simple discourses. ${ }^{24}$ The analysis of the data occurred in the following way: initially, we organized the material collected through the interviews, writing them out in full; following that, we undertook skim reading of the information gathered. After this first reading, we initiated a more in-depth reading of the material collected, with a view to recording impressions on the messages emitted, allowing us to group the accounts around the following categories: religious support, family support, support from friends, and support from the Calafate Women's Collective. The interpretation of the data was based in SRT and in theoretical knowledge regarding social support.

\section{RESULTS AND DISCUSSIONS}

The study subjects were adult women with a history of experiencing conjugal violence. They were black, stating themselves to be black or of mixed black/white descent; they stated that they had little formal education, with only two of them having finished senior high school; they were working as maids or were employed informally, being paid up to one minimum salary; they depended economically on their partners, totally or partially; and had up to six children.

The women interviewed indicated the importance of social support in regard to strengthening them and preparing them to confront the coming context. This social representation is permeated by central thematic categories, namely, religious support, family support, support from friends, and support from the Calafate Women's Collective.

\section{Religious support}

The study revealed that the women have religion as one of their main support resources, principally at times of great weakness and pain, as we can see in the following accounts:

[...] leaving it is really difficult. It is a type of violence which weakens, which annuls the woman [...]. The Candomblé helped me, because we have to hold on to a spiritual issue [...]. I saw the strength which it brought (Hera).

He used to assault me verbally, swearing at me, saying things that I didn't do. [...] I didn't leave the relationship because I liked him. I thought how he treated me was normal [...]. I think that before, I wasn't alive [...]. The Candomble also helped me a lot, I used to go to the meetings, the sessions, and speak with the spirits who came. So, she [the spirit] said that he wasn't the man for me. Participating in the Candomble also helped me not to be depressed (Aphrodite).

Of the 11 women interviewed, seven mentioned religious support. All mentioned the Candomblé. It is worth considering that all the interviewees stated that they were Afro-Brazilians, and that the population of Afro-Brazilians in Salvador is approximately $83 \%$, and the Candomble currently is not one of the more commonly-followed religious practices in the municipality: $60.54 \%$ of the population is Roman Catholic and only $0.49 \%$ follows the Candomblé. ${ }^{25-26}$ This space became a universe of sociability for the black community, whose family links, the "saint's family", tended to be protected and even legitimated. ${ }^{27-28}$

Regardless of the particular religion, the study shows that the women feel strengthened when they seek religious support, and this suggests that spirituality allows one to bear the difficulties of life and death. Many studies on the social support network have also shown religious leaders as the most-sought social resources, as they show concern with the other and value this other, and because of this effectively promote social links. As social structures, the religious organizations form part of the social support network, which aims to give support to people, leading them to believe that they have value and that they are accepted by a group. Hence, religion is one of the social support networks sought most by women in situations of violence. ${ }^{6,20}$

\footnotetext{
* An Afro-Brazilian religion originating from beliefs held in different parts of Africa, which arose among slaves transported to Brazil. Translator's note.
} 
The beliefs are grounded in symbolical thinking and are embodied in specific structures such as churches or clans, enabling the people to live. ${ }^{21}$ This being the case, the representation of religion as a force for liberation, able to save them from suffering, generates in these women the hope for a relationship without violence, which comes to give meaning to their lives.

\section{Family support}

The representation of family support as an essential element for the women's empowerment was also revealed in the study. The search for support from the families is indicated as a strategy for self-protection, so as to avoid further victimization, as family members care for each other, ${ }^{29}$ this being fundamental for the strengthening of the woman, as we can see in the following accounts:

I had already suffered nearly all the types of violence from this man. [...] from wanting to stop me walking with my friends, me going out [...]. He would hit me [...]. I don't know what would have been of me if it hadn't been for my mother's support. I wouldn't have had the courage. She talks a lot, supporting me [...]. She said: 'dump this man and come home!' That was when I left. She also helps me financially (Gaia).

my family supported me in all senses [...]. They didn't oblige me to stay with him because they knew that he was mistreating me. They knew about everything I was going through [...]. A lot of families don't support the separation. They think that because the person married that man, no matter how worthless the man is, if he hits her, they think that she has to stay with that man (Aphrodite).

In summary, members of the interviewees' families constituted social support, offering emotional support, advice and material resources, which are elements which make up the principal functions of a social support network. ${ }^{19}$ Furthermore, these attitudes offer the interviewees well-being and mitigate the suffering, giving them strength such that they may seek a life free of violence.

The support from the members of the family causes the individual to feel cared for, loved and wanted. This support - which is not restricted to the emotional sphere and which extends to other resources available - is given in such a lasting way that it allows people's physical and psychological well-being. ${ }^{14,30}$

The women's accounts reveal the value attributed to their families, making clear their representation as a base of support. On the other hand, lack of support on the part of the family hinders the process of breaking the cycle of violence, and entails even greater suffering for the woman.

It was difficult to rent a house and have to take care of myself, alone, with a daughter [...]. I had to just go ahead [...]. I didn't have the support of my family, of anybody. If you get a kilo of rice and drop it on the ground, then pick it up, when you put it back on the scales there won't be a kilo any more. Something is always lacking [...]. I will not be able to pardon them because when I needed their support most, they did not support me [...]. You get disappointed by your family [...]. I cry because I get embittered by this and the bitterness is still in me now. I think there is no cure (Athena).

As could be observed in the account, the relationship with the family members was not always a source of support for some participants who, due to this, were not able to resort to the same at times of distress. One study grounded in SRT reveals that the social representations of people who allege the absence of family support are anchored in feelings of abandonment. ${ }^{31}$ The lack of family support, in its turn, hinders the process of the woman's empowerment to leave the cycle of violence and begin a new life.

The long-lasting social representations are presented in a way that is so ingrained, so powerful, that it is almost impossible to overcome them. ${ }^{21}$ From this perspective, when the family - considered the biggest source of support - does not meet expectations, the woman ends up feeling even more isolated, given that the attitude of expecting family support is in accordance with the common knowledge which creates the substrate of the images and meanings of "family". It is worth emphasizing that the representation of the family as a source of support is anchored in the image of the ideal family, in which all the members are united and there is no space for conflicts. The real family, however, is not necessarily like this.

\section{Support from friends}

In the representations of women with histories of experiencing conjugal violence, friends' support was of great help, given that this empowers them and, on many occasions, encourages them to break away from the relationship permeated by violence, as we can see below:

for me, the worst phase was in the phase of pregnancy. [...]. That was the time when he made me suffer most, when he tortured me most [...]. I lost my self-esteem [...]. You mustn't keep it to yourself, because 
the more you keep it to yourself, the more it lowers your self-esteem [...]. You talk with a neighbor, you let off steam with your friend, you talk, you open up [...] As there are ways for you to leave (Persephone).

[...] knowing that there are people who will embrace you without judging [...] a form of attendance which is not legalized, which is informal, which strengthens you [...]. She [the friend] also has a history of experiencing violence, she has a deep understanding, without judgment, without anything. She cried a lot with me. So, this is what gives you strength. [...] I managed to get my self-esteem back, get back my self-esteem, see the horizon, see other goals (Hera).

Friends and neighbors have been indicated in various studies as efficacious resources for social support in the environment in which we are inserted. As they are persons in whom one can trust, and on whom one can rely in adverse situations, interpersonal relationships with people who are friends allow the sharing of emotions and feelings, as well as the feeling of protection. This form of support allows the woman to take her life in another direction, this being one of the functions which the social network can perform in relation to an individual. ${ }^{14,19,30}$ In addition, feeling oneself to be supported by friends reduces the chances of anxiety, depression and somatic illnesses related to stressful situations. ${ }^{14,30}$

It may be noted that many studies, both old and current, indicate friends as social support, indicating that this representation has passed across generations and has been maintained until the present day. The strength of a representation is the result of the pre-established structure and of tradition, which decrees what must be thought. ${ }^{21}$ Nevertheless, some interviewees complained about feminist colleagues who - on learning of their history of conjugal violence and that they were remaining in the relationship - judged them instead of demonstrating solidarity and understanding regarding the complexity of this experience, thus revealing themselves not to be a source of social support:

I thought that the feminists would judge me, as some did judge me. They do not show solidarity. They think we are already ready, that we are anti-patriarchal women. And that is not the case. Although it was good in a way because I expect less from women in the process of leaving situations of violence (Hera).

I know that I am not the only feminist to have suffered violence [...]. I have become stronger, and I see that I can strengthen other feminists who live in situations of violence (Aphrodite).
It is worth emphasizing that of the 11 women interviewed, four described themselves as feminists. The term "feminist" relates to women who question the roles which are attributed to them and argue for equality of rights between men and women, including the right to a life without violence. Since the 1970s, the Feminist Movement has appeared in Brazil as a women's movement, making conjugal violence more visible in the public sphere. ${ }^{32}$

Attention is called to the fact that feminists are not free from suffering violence in relationships with their partners, and that they also judge women who pass through the same situation. It may be noted that the judgments are shared by society as a whole. Common knowledge, structured by past generations, continues to be conceived of as an archaic stage of understanding regarding knowledge which is not changed, and which is passed on in daily life, in such a way that people do not reflect about the shared common knowledge. ${ }^{21}$ The need for understanding is indicated, not only of the social construction of the inequality between men and women, but mainly of the complexity which permeates its internalization and reproduction, which is responsible for the naturalization of violence against women in our society.

Although feminist colleagues did not represent social support to the interviewees, it is worth emphasizing that these mobilize other resources of their social network in order to seek conditions for confronting the adversities. A sensitive, active and trustworthy social support network is essential so as to cause the other to experience being the protagonist in her own life and to accelerate the processes of cure, and is, therefore, a generator of health. ${ }^{19-20}$

\section{Support from the Calafate Women's Collective}

The Calafate Women's Collective, as an NGO, showed itself to be an important social support for women in situations of violence. Other studies have confirmed that NGO are actioned as local sources of social support, ${ }^{13}$ empowering people for taking decisions. The accounts below illustrate the support viabilized by the NGO:

the only place that I came to get help and to understand what I was going through is right here [the Calafate Women's Collective], because here I learned how it is, what you do, of which women don't have to do everything, and that us women must not accept the violence [...]. This changed my relationship a lot. It improved (Hestia). 
I think that before, I wasn't living. Today, I can go out, I can come home, I don't owe satisfaction to anybody, I can do what I want, wear what clothes I want, put on eyeliner, put on lipstick, all these things that he didn't like me doing, they were all ways in which he was abusing me, but I didn't know that I was experiencing a situation of violence [...]. When I began to notice that it wasn't normal, I had to say enough [...]. Everything that I didn't do when I was with him, I do nowadays, and today I see that I live better. I was a person who didn't have the happiness that I feel today (Aphrodite).

[...] this progress all happened after I entered the Collective. It opened my mind [...]. After I began to come along and participate in the workshops, I began to recover my self-esteem. After, I saw that all of that was violence, I put a stop to it. I began to change [...]. I no longer feel abused. Nowadays our relationship has actually improved (Persephone).

The accounts reveal that educational activities undertaken by the CMC cause the women to better understand the inequality between men and women and the naturalization of the social roles, which allows them to recognize that they are in situations of violence and to reflect on their lives. The women confirm that they recovered their selfesteem through participating in the activities of the NGO, which allowed them to become aware of their value, trust in themselves, and - in this way - find the strength to take decisions and seek exits.

In this way, one can perceive the importance of information in the process of transforming the conjugal relationships. The access to information and to means of communication is one of the ways which promote the reduction of any individual's vulnerability. The acquisition of new knowledge is articulated, transforming the group's perceptions and values regarding an object, such that it allows the modification of the representations, as these reflect the direct experience which one has with a specific situation. ${ }^{33}$

In the social relationships, the representations undergo a continuous process of construction, deconstruction and reconstruction, society being the space for the forming, sustentation and transformation of objects, to the extent in which the representations change. In this case, the world of the human beings seeking a new praxis is also changed. ${ }^{21}$ Hence the importance of the women's movement, in relation to giving a new direction to the conjugal relationships.

The nature of the change, based upon which the social representations become capable of influencing a group's behavior, guiding it towards that which must be responded to, is important. It is known that the understanding of the new is influenced by the dissemination of information, and that this does not circulate either in all the groups, or in the same way, being influenced by educational resources, professional interests, ideologies, beliefs, and values, elaborating representations which are more solid or fluid regarding an object. ${ }^{21}$ In this context, the CMC is revealed as social support for women in situations of violence.

\section{FINAL CONSIDERATIONS}

Support from religion, from family members, from friends and from an NGO - the Calafate Women's Collective - makes up the social support network of women in situations of violence who live in the community of Calafate, in Salvador (in the state of Bahia, Brazil). Considering the specific characteristics of this group of women in this study, these forms of support were revealed to be elements which empowered them for confronting the situation of conjugal violence. The importance of the social network as a coping strategy for adverse situations, such as, for example, the experience of conjugal violence, is therefore indicated.

The interrelationship between the women and these elements of social support strengthens them, either because of the emotional, spiritual or material support, or through the information itself. These social links established allow the women to feel supported, which promotes the recovery of their self-esteem and viabilizes the exercising of their becoming the subjects of their history, in the sense of being able to see horizons in their search for life without violence.

The fundamental role of the professionals who work in the health spaces should be highlighted, in particular nursing, in regard to noting the woman in her family and social context, identifying vulnerabilities and/or health issues, such as conjugal violence; and, based on that, to implement health promotion actions. In this ambit, knowledge regarding the social support network available in the community is essential, especially when the elements which make this up reflect the representations of a specific group which has already experienced conjugal violence; it is therefore configured as common knowledge shared by this group.

It is worth highlighting the importance of the Calafate Women's Collective. The educational activities which it made available allowed the women 
access to information which, when articulated with already-held knowledge, contributed to the process of transforming the representations. Considering that the social representation guides human behavior and that its reconstruction is influenced by the access to information, we can say that the NGO in question directs the women to an action directed towards breaking the cycle of conjugal violence.

These spaces can be viabilized, including with the participation of the men, through extension projects in the social area, supported by teaching institutions and encouraged through developmental bodies. They can also be promoted by the articulation of the Departments of Health, Social Action and Education, for example, through the viabilization of articulated actions between the Family Health Strategy, the Social Assistance Reference Center, and schools from the municipal and state network.

The representations grasped made it possible to understand the ways that women act regarding the experience of conjugal violence, indicating the forms of social support which these seek when faced with crisis situations. It also made it possible to investigate some of the social resources available in the community. However, as the study is limited to a specific group, investigations are necessary so as to reveal other forms of social support which help people in situations of vulnerability, these not being restricted to conjugal violence. It is equally relevant to insert, into the training of professionals who work in health settings, spaces for discussion and dissemination relating to the support network for women in situations of violence, considering the importance of family members, friends, religion and NGO in the process of women's empowerment.

\section{REFERENCES}

1. Ministério da Saúde (BR), Secretaria de Atenção à Saúde. Prevenção e Tratamento dos Agravos Resultantes da Violência Sexual contra mulheres e adolescentes: norma técnica. $2^{\mathrm{a}}$ ed. Brasília (DF); 2005.

2. Schraiber LB, Oliveira AFPL, Falcão MTC, Figueredo WS. Violência dói e não é direito: a violência contra a mulher, a saúde e os direitos humanos. São Paulo (SP): Editora da Unesp; 2005.

3. Convenção de Belém do Pará. Convenção Interamericana para Prevenir, Punir e Erradicar a Violência contra a Mulher, 1994.

4. Meneghel SN, Hirakata VN. Femicídios: homicídios femininos no Brasil. Rev Saúde Pública. 2011 Jun; 45(3):564-74.
5. Organização Pan Americana de Saúde. Información y análisis de salud: situación de salud en las Américas: indicadores básicos. Washington (US): OPAS; 2009.

6. Schraiber LB, Barros CRS, Castilho EA. Violência contra as mulheres por parceiros íntimos: usos de serviços de saúde. Rev Bras Epidemiol. 2010; 13(2):237-45.

7. Vieira EM, Perdona GCS, Almeida AM, Nakano MAS, Santos MA, Daltoso D, et al. Conhecimentos e atitudes dos profissionais de saúde em relação à violência de gênero. Rev Bras Epidemiol. 2009; 12(4):566-77.

8. Vieira LJES, Pordeus AMJ, Ferreira RC, Moreira DP, Maia PB, Saviolli KC. Fatores de risco para violência contra a mulher no contexto doméstico e coletivo. Saúde Soc. 2008 Jul-Set; 17(3):113-25.

9. Schraiber LB, d'Oliveira AFPL. Romper com a violência contra a mulher: como lidar desde a perspectiva do campo da saúde. Athenea Digital. 2008; 14:229-36. [acesso 2010 Jul 25] Disponível em: http:/ / www.redalyc.org/articulo.oa?id=53701414

10. Ministério da Saúde (BR), Secretaria de Políticas para as mulheres (SEPM). Balanço central de atendimento à Mulher. 2010. [acesso 2011 Ago 28]. Disponível em: http://www.spm.gov.br/noticias/ ultimas_noticias/2010/10/balanco-da-central-deatendimento-a-mulher

11. Almeida I, Soeiro C. Avaliação de risco conjugal: versão para polícias (SARA: PV). Anál Psicológica. 2010 Jan; 28(1):179-92.

12. Brasil. Lei n. 11.340, de 7 de agosto de 2006. Dispõe sobre mecanismos para coibir a violência doméstica e familiar contra a mulher. [acesso em 2012 Set 27]. Disponível em: http://www.planalto.gov.br/ ccivil_03/_ato2004-2006/2006/lei/111340.htm

13. Schraiber LB, Barros CRS, Castilho EA. Violência contra as mulheres por parceiros íntimos: usos de serviços de saúde. Rev Bras Epidemiol. 2010; 13(2):237-45.

14. Speck, RV. La intervención de red social: las terapias de red, teoría y desarrollo. In: Elkaim M. La práctica de la terapia de red. Barcelona (ES): Gedisa; 1989.

15. Marques ECL, Bichir RM. Redes de apoio social no Rio de Janeiro e em São Paulo. Novos Estudos CEBRAP. 2011 Jul; 90:10-32.

16. Wethington E, Kessler RC. Perceived support, received support and adjustment to stressful life events. J Health Soc Behaviour. 1986; 27(1):78-88.

17. Marconi MA, Lakatos EM. Metodologia científica. $5^{\mathrm{a}}$ ed. São Paulo (SP): Atlas; 2008.

18. Cobb S. Social support as a moderator of life stress. Psychosom Med. 1976 Fev; 38(5):300-14.

19. Sluzki CE. A rede social na prática sistêmica. São Paulo (SP): Casa do Psicólogo; 1997.

20. Bullock K. Family social support. Conceptual frameworks for nursing practice to promote and 
protect health. In: Bomar PJ. Promoting health in families. Applying family research and theory to nursing practice. Philadelphia (US): Saunders; 2004.

21. Moscovici S. Representações sociais: investigações em psicologia social. Trad Pedrinho A Guareschi. $6^{a}$ ed. Petrópolis (RJ): Vozes; 2009.

22. Triviños ANS. Introdução à pesquisa em ciências sociais. São Paulo (SP): Atlas; 2006.

23. Strauss A, Corbin J. Pesquisa qualitativa: técnicas e procedimentos para o desenvolvimento de teoria fundamentada. $2^{\text {a }}$ ed. Porto Alegre (RS): Artmed; 2008.

24. Bardin L. Análise de conteúdo. $70^{a}$ ed. Lisboa (PT); 2009.

25. Salvador. Secretaria Municipal de Saúde; Grupo de Trabalho de Saúde da População Negra. Diagnóstico de saúde da população negra de Salvador. Salvador (BA); 2006.

26. Sistema de Informação Municipal de Salvador (SIM). 2009. [acesso 2009 Jun 11] Disponível em: http:/ / www.sim.salvador.ba.gov.br/indicadores/indext. php

27. Lima VC. Família de santo nos candomblés jejenagôs da Bahia: um estudo de relações intra-grupais [dissertação]. Salvador (BA): Universidade Federal da Bahia; 1997.

28. Reis ICF. A família negra no tempo da escravidão: Bahia, 1850-1888. [Tese]. Campinas (SP): Universidade Estadual de Campinas; 2007.

29. Snow DL, Swan SC. The development of a theory of women's use of violence in intimate relationships. Violence Against Women. 2006 Nov; 12(11):1026-45.

30. Fonseca IS, Moura SB. Apoio social, saúde e trabalho: uma breve revisão. Psicol Am Lat. 2008 Dez; 15(sp).

31. Santos MA, Vieira EM. Recursos sociais para apoio às mulheres em situação de violência em Ribeirão Preto, SP, na perspectiva de informantes-chave. Interface - Comunic. Saúde Educ. 2011 Jan-Mar; 15(36):93-108.

32. Bruschi A, Paula CS, Bordinm IAS. Prevalência e procura de ajuda na violência conjugal física ao longo da vida. Rev Saúde Pública. 2006 abr; 40(2):256-64.

33. Boas LPSV, Souza CP. Representações sociais e história: limites e possibilidades. In: Moreira ASP, Camargo BV, organizadores. Contribuições para a teoria e o método de estudo das representações sociais. João Pessoa (PA): Editora Universitária da UFPB; 2007. 